\title{
Technological Tools for the Improvement of the Mass Transport System (MTS) in the Caribbean Region of Colombia
}

\author{
Hugo Hernández Palma ${ }^{1}$, Andrés Porto Solano², Mariangelica Pineda Carreño ${ }^{3}$, Maribel Molina Correa ${ }^{4}$ and \\ Cecilia Correa de Molina ${ }^{5}$ \\ ${ }^{1}$ Researcher, Universidad del Atlántico, Barranquilla - Colombia \\ ${ }^{2}$ Researcher, Corporación Universitaria Americana, Barranquilla - Colombia \\ ${ }^{3}$ Researcher, Corporación Universitaria Americana, Barranquilla - Colombia \\ ${ }^{4}$ Researcher,Corporación Universitaria Americana, Barranquilla - Colombia \\ ${ }^{5}$ Researcher, Universidad Simón Bolivar, Barranquilla, Barranquilla - Colombia
}

\begin{abstract}
The present article aims to make a critical view of the current and prospective situation of mass transport systems in the Caribbean region based on technologies. One of the important and sensitive aspects of analysis is the impact that these systems are generating in the economic, social and environmental conditions. While the integration of the various modes of transport at the national level has made notable progress, in the Caribbean region the implementation of similar systems is only in the preliminary stage. Then, essential aspects will be reviewed for the development of mass transport systems and simultaneously assess how technological development can generate contributions to expedite the process of the same and finally the most representative and reflections of general interest will be stated
\end{abstract}

Keywords-technological development; mass transportation; infrastructure; Caribbean region

\section{INTRODUCTION}

Recent studies on the impact of globalization on the regional economy shows a general trend where capital cities and district governments punctuate more dynamic infrastructure projects and development in each city or region. This leading role where natural leadership is imposed without exclusive reliance on a centralized government, It is the result of self-management processes and use of resources of all kinds [1], [2], [3].

In analyzing the various investment projects and greater attention boom has generated in cities in Colombia, and that given the global economic direction and seeking to achieve sustained development in the long term, emerge Mass Transit Systems (MTS), in response to a need for transformation and competitiveness, to give new impetus and achieve the renewal of cities at regional level. It is undeniable that when cities have transport platforms, sustainable, technologically advanced, modern and safe, investors and other estates are involved with any activity attraction intending to develop in the same [4].

It is necessary to deepen the context of major projects that the country has been deployed through a critical analysis of previous initiatives, delving into the projection from the technological point of view that can watch for MTS. The main objective of the study is to evaluate the influence of the MTS in the region, through critical analysis of the most outstanding technological aspects, concepts and characters that can be valued in the future

\section{THE REPUBLIC OF COLOMBIA AND MASS TRANSPORT SYSTEMS}

Checking on objectives and impacts Integrated Mass Transportation Systems (MTS) through the bus rapid transit (BRT) they have had on the reengineering of the cities and municipalities of a locality or territory, it can be said that the quality of socio-economic levels has improved to the extent that people are able to travel as much distance in the shortest time possible [5].

The benefits associated with the implementation of the MTS conglomerate summarized on monetary, environmental and social impacts; Also and a little more specific benefits are: lower accident rates, recovery in land prices, urban development, among others [6],[7],[8],[9],[10].

Within the literature on the impacts of the implementation of MTS, the authors found Ibañez Echeverry and Moya [11] in (2005) and Chaparro [12] in (2002) who value the social benefits economically around reductions in deaths and traffic accidents before and after implementation of an MTS in the cities of Cali (MIO) and Bogota (TRANSMILENIO) respectively.

Similarly the author Medrano [13] in (2003) conducted a descriptive analysis of social impact without monetary quantification, of reducing accidents by implementing the first phase of SMT in Bogota (TRANSMILENIO). Bocarejo [14] in 2012, further expands the author's analysis Medrano (2003) by detailing the locations geographically more reduction of accidents in the city of Bogota with the implementation of the MTS.

The National Planning Department of Colombia (DNP) [15] also assessed positively in 2011, generated from the reduction 
of accidents by implementing MTS, in the city of Pereira (Bus) and Cali (MIO) contractual benefits.

\section{SCREENING OF THE CARIBBEAN REGION THROUGH THE MTS}

The Caribbean region is one of the five major regions that make up the Republic of Colombia in South America and is located north of it. Of the major cities that make up this region are the cities of Barranquilla, Cartagena, Santa Marta, Valledupar and Sincelejo. Bearing in mind the last official national census is identified that the Colombian Caribbean region represents at least a $23 \%$ (rounded) of the total national population, with a considerable number of population will require innovation and special focus on platforms mass transport.

Infrastructure management in the Caribbean Region has developed from a territorial platform, resulting from the decentralization processes of each of the departments and cities of the region have been conducted. According to historical data analyzed. This process began around the year 1983 and it has been materialized to the extent that systems of governance at the local level have been advancing in levels of planning and development [4].

This new approach has enabled replace traditional patterns of centralized governance that was typical of the twentieth century, and it contemplated that large projects could only be managed from the central government [16].

Nowadays self-management or local management, it has gained strength and by incorporating dynamic governance more strategic, it has consolidated the implementation of large infrastructure projects, which has promoted and sustained in major urban centers of the Caribbean region exponential development.

Since the origin and settlement of regional cities, transport has had a direct relationship with the development of these, having an optimal system and adjusted to the socio-economic needs of each locality has provided regional level the phenomenon of metropolization, consisting of the facility to travel long distances from a strategic point or equidistant, in the shortest possible time [17].

Characterizing this impact can generate for a city an MTS optimum; it is undoubtedly a substantial contribution to the consolidation of development plans with a view to reaching a global performance in the region. Getting the design and implementation of solutions for efficient, modern, technologically advanced and safe transport, competition requires both locally and nationally, to maximize the power of coordinated efforts [18]. This and the fact of taking into account the initiatives proposed projects impact large urban transport level, as the focus of promotion for regional growth.

\section{URBAN RENEWAL IN COLOMBIA AND IN THE}

\section{CARIBBEAN REGION THROUGH THE IMPLEMENTATION OF MTS}

Until a few years ago going to work in cities like Barranquilla (Atlántico) was a task that could take up to 60 minutes depending on the starting point and the destination point of the individual, with the launch of the MTS in the city (TRANSMETRO) which came into operation in 2010 [19], this time has been cut by 50\%, improving the quality of life of people by reducing mobilization times.

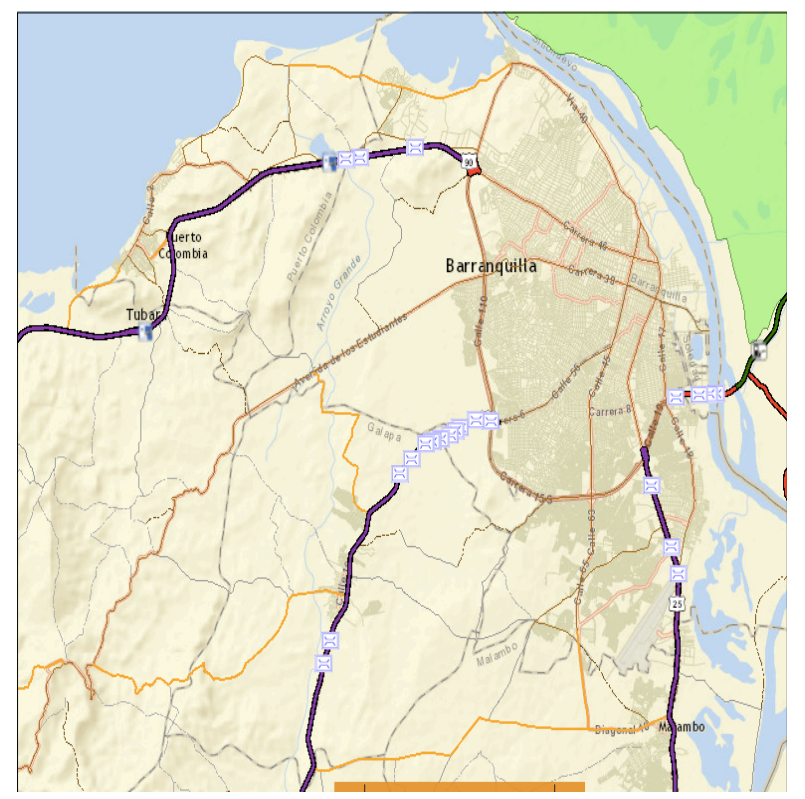

FIGURE I. ROAD MAP - INVIAS (METROPOLITAN AREA OF BARRANQUILLA, STREETS)

Cities like Barranquilla, Soledad, Galapa and Cartagena have had to undergo a process of improvement and redesign of the road network which has promoted among other benefits: third-generation roads, pedestrian areas, and revival of green areas, cycle tracks and incursion, the most noticeable change in this process [20].

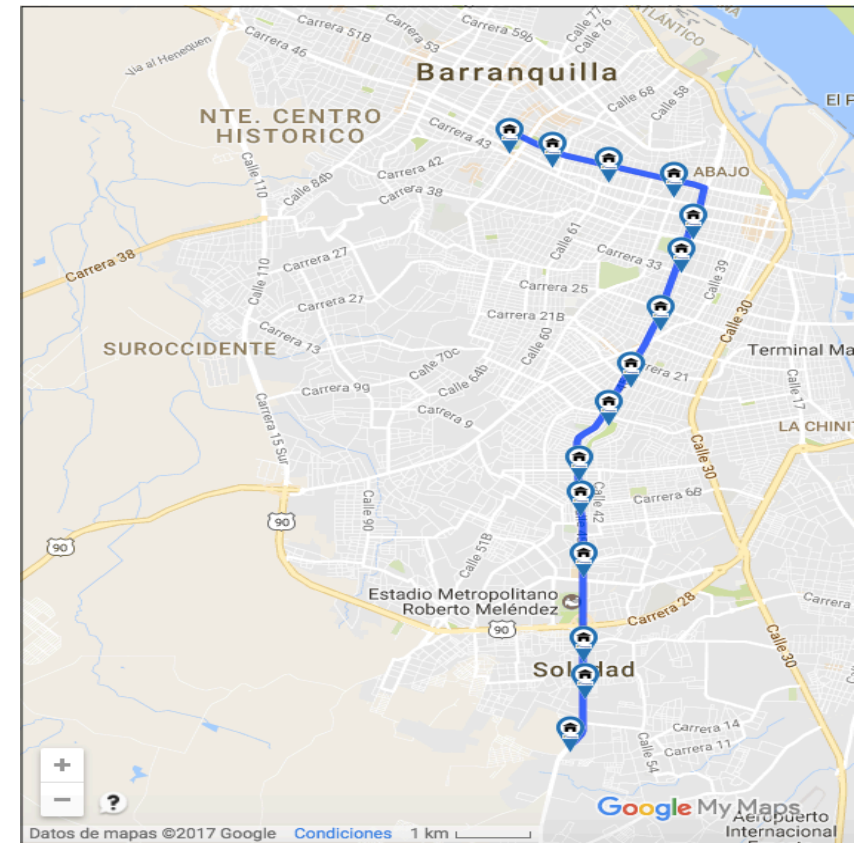

FIGURE II. TRANSMETRO ROAD MAP (METROPOLITAN AREA BARRANQUILLA-SOLEDAD VICE VERSA) 
Simultaneously, the urbanization process has made great achievements, while municipalities in the metropolitan area of the capital cities have successfully integrated development hull parallel to the implementation of the MTS, thus we find that municipalities like Soledad (Atlantic) achieves connection to Barranquilla (the capital city), only 10 minutes this becomes a differentiating factor for the working community [21]. We find similar case in Cartagena, where some outlying areas are already connected by TRANSCARIBE, with the business and commercial center of the city [22].

One of the major axes of business, commercial and social momentum, has been the technological development that has inherent brought the launch of the new MTS [22]. Before the existence of these new transport systems, daily activity was spent in the traditional and basic form applied in all municipalities and localities in the region. The collection was entirely in cash, stimulated called penny war where the same transport drivers competing unfairly to attract more passengers. Such practices fomented among other issues: passenger overcrowding, problems of insecurity permanent cash handling and additionally, security problems by the lack of a culture of prevention for vehicles used for transport [23].

With the advent of new vehicles, incorporating software for controlling and monitoring collection fleet and articulated has successfully managed from the field of technology, substantial improvements not only cause increased quality of life of users, but also create a safer environment attenuated risks and brought under control [23].

In addition to the above, is the fact the large developed portals for entry and exit of users; have adequate, marked and modernized spaces, has created an environment that allows interaction and strangers, determine the routes of interest with ease [24]. All this complemented with interactive applications that support consult the websites with different routes, schedules and portals, creating an atmosphere of full accessibility to MTS. This ease of interaction is welcomed especially by the student community, who by having greater control of social networks, have become a benchmark for school, family and general environment for the whole community.

\section{CONCLUSIONS}

Looking at the dynamics that have been deploying investment projects in the cities of the Caribbean region is undeniable conceptualizing that investment projects in MTS loom large at the great involvement that they have in all dimensions of global growth for the region.

The MTS has generated a number of changes in infrastructure that not only contribute to urban renewal, but also promote technological development to achieve targets for coverage, services and controls.

The highlights in technological development at the service of transportation are now reflected in the different operating systems that have enabled, control and safety precautions (handling electronic card), accessibility through Web pages and applications and service customer in each of the portals through easy guidance systems and routing paths.
In the Colombian Caribbean MTS Region are at a preliminary stage of development, this allows a glimpse of the incorporation of notorious technological advances to the extent that local leadership, keep the dynamics of investment and public management focused on the consolidation of macro projects that allow, not only improve mobility in general, but also grow in technology to provide a fully interactive platform accessible to all users.

\section{REFERENCES}

[1] Lungo, M., "Globalización, grandes proyectos y privatización de la gestión urbana”, en Carmona, M. (Ed.), Globalización y grandes proyectos urbanos: la respuesta de 25 ciudades, Buenos Aires, Ediciones Infinito, 2005, pp. 48-55.

[2] Silvera Sarmiento, A. D. J. "Resignificación del tejido social en la relación escuela Comunidad. (Tesis doctoral inédita)". Doctorado en Ciencias de la Educación. Universidad Simón Bolívar, Colombia, 2016.

[3] González García, A., García García, Y., Gallego Quiceno, D., Sastoque Zapata, J., Ramírez Juidias, E. "Impacto medioambiental de la integración de la computación en la nube y la Internet de las cosas”. Producción + Limpia, 11(2), 22-30, 2016. DOI: 10.22507/pml.v11n2a2

[4] Departamento Nacional de Planeación (DNP). "Lineamientos para optimizar la política de desarrollo urbano”. Documento Conpes 3305 de 2004, Bogotá, DNP, 2004.

[5] Fox, Halcrow. "World Bank urban transport strategy review-Mass rapid transit in developing countries”. Final Report, World Bank, Washington, DC; 2000.

[6] Rodríguez, D., \& Vergel, E. "Sistemas de transporte público masivo tipo BRT (Bus Rapid Transit) y desarrollo urbano en América Latina”. Land Lines, 25(1), 16-24; 2013.

[7] Perdomo, J. A. "A methodological proposal to estimate changes of residential property value: Case study developed in Bogota". Applied Economics Letters, 18(16), 1577-1581, 2011.

[8] Cosme, S., \& Oliveira, P. “Transport Infrastructure Impact Evaluation”, $2010 . \quad$ Recuperado de: http://intranet. imet. gr/portals/0/usefuldocuments/documents/02673. pdf (marzo de 2013)

[9] Banco Mundial. "Project Appraisal Document On A Proposed Loan In the Amount of US\$250.0 Million to the Republic of Colombia for the 240 Integrated Mass Transit Systems Project”, 2004. Recuperado de: http://documents.

worldbank.org/curated/en/2004/05/3659918/colombia-integratedmasstransit-systems-project (marzo de 2013)

[10] Perdomo, J., \& Arzuza, M. "Beneficio económico de Transmetro sobre la reducción de la accidentalidad vial en el área metropolitana de Barranquilla, Colombia”. Lecturas de Economía, (82), pp. 219-245, 2015.

[11] Echeverry, Juan Carlos; Ibañez, Ana María y Moya Andrés. "Una evaluación económica del sistema TransMilenio”, Revista de Ingeniería, No. 21, pp. 68-77, 2005.

[12] Chaparro, I. "Evaluación del impacto socioeconómico del transporte urbano en la ciudad de Bogotá: El caso del sistema de transporte masivo, Transmilenio” (Vol. 48). United Nations Publications. 245, 2002.

[13] Medrano, Andrés. "La Accidentalidad de un Medio Masivo de Transporte Público para la Ciudad de Bogotá, Transmilenio. Proyecto de Grado en Ingeniería Civil Departamento de Ingeniería Civil y Ambiental” Facultad de Ingeniería, Universidad de los Andes, 2003.

[14] Bocarejo, J., Velasquez, J., Díaz, C., \& Tafur, L. "Impact of bus rapid transit systems on road safety: Lessons from Bogotá, Colombia”. Transportation Research Record: Journal of the Transportation Research Board, (2317), pp. 1-7, 2012

[15] Departamento Nacional de Planeación. "Valoración y cuantificación de los resultados alcanzados con la implementación del SITM de Cali, y análisis costo-beneficio del Sistema, comparando los objetivos trazados en el diseño conceptual, los documentos CONPES del SITM de Cali y la situación real actual del Sistema”, 2011 Recuperado de: https://sinergia.dnp.gov.co/Sinergia/ Archivos/3134003f-d5a9-441a9998-7585fbac68c5/Informe_Final_ 
Sistema_Transporte_Masivo_CALI.pdf (marzo de 2013),

[16] Miranda, L. "La gestión urbana en la ciudad colombiana. Una agenda por construir y unos logros por consolidar”, Bogotá, Mimeo, 2008

[17] Miranda, L., Torres, A., Hurtado, A. "Gestión metropolitana: apuntes para un marco teórico”. Maestría en Gestión Urbana, Universidad Piloto de Colombia (inédito), 2011

[18] Monzón, A., "Gestión del transporte metropolitano”, en Rojas, E.; Cuadrado-Roura, J. y Fernández, J. (Edits.). "Gobernar las metropolis”, Washington, Banco Interamericano de Desarrollo (BID), 2005.

[19] Hurtado A. \& Hernández, M. “Transmetro Barranquilla-Soledad: retos para la gestión metropolitana en un contexto de desequilibrios territoriales”. Revista Pensamiento y Gestión. Vol. 34, 2013. ISSN 2145-941X (online).

[20] Carmona, M. "Globalización y cambios conceptuales en el desarrollo urbano”. En: M. Carmona (Ed), Globalización y grandes Proyectos Urbanos: la respuesta de 25 ciudades pp.48-55 Buenos Aires: Ediciones Infinito, 2005.

[21] Cartagena como Vamos. "Retos para la socialización y apropiación de Transcaribe”, 2017.

[22] Consultado en: http://www.cartagenacomovamos.org/retos-para-lasocializacion-y-apropiacion-de-transcaribe/

[23] Cervero, R. "The Transit Metropolis: A Global Inquiry”, Washington, Island Pres, 1998.

[24] Cámara Colombiana de la Infraestructura - CCI. "Informe Sistemas Integrados de Transporte Masivo - SITM”, Julio 2011. Ver en: http://www.infraestructura.org. co/seguimientoproyectos/InformeSITM Julio2011.pdf.

[25] Alfonso, O. "Impactos socioeconómicos y demográficos de la metropolización de la población colombiana y de los mercados de trabajo y residenciales". Documento de Trabajo, 31, Universidad Externado de Colombia, 2010. 